\title{
William Mark Waddoups And His Kalaupapa Connection
}

\author{
FRED E. WOODS
}

Few OUTSIDERS during the early twentieth century made the descent to the Kalaupapa leprosy settlement on Moloka'i more frequently or with more impact than William Mark Waddoups. Waddoups, a selfeffacing farm boy, was born in 1878 and spent his youth on a modest farm in Bountiful, Utah, where he undoubtedly cultivated a strong work ethic discernible throughout his life. Concerning his childhood, William wrote, "My boyhood experiences were little different to those of thousands of boys of our time raised as I was on a farm. . . . A constant source of wonder and interest were the trains which passed and re-passed our home several times daily. ... These great trains, passing daily, inspired me with ambition to see the world and take my proper place in it."1

His first opportunity to leave his rural farm setting and experience the outside world occurred when he left on a mission to Hawai'i at age 22. Concerning his mission call and the acquisition of the Hawaiian language, he wrote,

Fred E. Woods is a professor at Brigham Young University in Provo, Utah and has lectured extensively in the United States and internationally. He also authored many academic articles and books, including several works on Hawaiian history. His most recent publications are Kalaupapa: The Mormon Experience in an Exiled Community (2OI7), Reflections of Kalaupapa (2OI7), and Sacred and Historical Places Hawai'i: An LDS guide to Historic Places (2OI 6) which he co-authored with Mary Jane Woodger and Riley Moffat.

The Hawaiian Journal of History, vol. $5^{1}$ (2017) 
In January 1900 I was called on a mission, through John W. Taylor to the Colorado Mission. President Joseph F. Smith, changed the call to Hawaii and I accordingly left home for Hawaii in February in company with Angus Smedley. We traveled steerage on the S.S. Alameda. My brother Anson was in Hawaii having been there doing missionary work for three years. ... Much of my time was spent studying the Hawaiian language. ... This was a great blessing to me as Anson had a very good knowledge of Hawaiian and helped me very much indeed. I labored with him in Honolulu until October 1900 when he was released to return home. ${ }^{2}$

\section{First Visit to the Kalaupapa Settlement}

Waddoups served as a Latter-day Saint (LDS) missionary in the Hawai ' $i$ Mission from 1900 to 1904 , where he grew to have a tremendous love for the local island people. Over time, he became fluent in the Hawaiian language and comfortable living in Hawai'i, which included time spent at Kalaupapa, a place he would return to time and again for decades. In April 1904, his last assignment in the mission field was to travel, with his companion David Johnson, to dedicate the LDS chapels at both Kalawao and Kalaupapa on Moloka 'i. ${ }^{3}$ At this time the Mormon population at this leprosy settlement had increased to at least two hundred, which included the recent baptisms of ten new Mormon converts, making the LDS members just over 20 percent of Kalaupapa's total population in the settlement. ${ }^{4}$

The following article, written by Waddoups in 1904, appeared in the LDS periodical the Deseret Evening News, titled "Mormon Elders' Work in a Leper Settlement."

The Hawaiian leper settlement is one of the many points of interest in the Hawaiian territory. It is situated on a small strip of land of only two or three miles extent, on the island of Molokai, about $5^{2}$ miles direct from Honolulu. It is a natural prison, surrounded by the ocean and high precipitous mountains. There are in the neighborhood of nine hundred souls now suffering from this dreaded disease and retained at this station.

The treatment of these unfortunates by the officials is the very best. They are furnished good food and clothing. They have clean, sanitary homes, and good medical treatment. They also have amusements of 
various kinds such as baseball, football, athletic clubs, dances, and various social functions. Educational advantages are good, as they have several excellent schools. Nor is their spiritual training neglected, for they have roomy, pleasant houses of worship and all is done for them that can be done.

Elder David Johnson and I had the privilege of visiting the settlement recently, for the purpose of dedicating the two meetinghouses for the Church of Jesus Christ of Latter-day Saints, one at Kalaupapa and one at Kalawao. These are some of the best houses in the Hawaiian mission.

The building at Kalaupapa has been in course of erection for about five years. It was built entirely from contributions, and finished only after patient, untiring effort by the Saints and friends of the settlement. We have now good houses where these unfortunates of God's children can meet to worship Him acceptably. Our Saints in this settlement are among the most faithful. Their faith seems unshaken in the truth. They are united in doing good, and their greatest joy seems to be in honestly serving the Lord.

They seem happy and contented with their lot, and many, if given the privilege of leaving the settlement, would choose rather to remain. I never felt a sweeter, calmer spirit among our Saints anywhere, than I felt in laboring with these people. Even in their trials, God has given them joy and contentment and a firm testimony of the divinity of the Gospel. Much praise is due to those who have the affairs of the settlement in hand. They are kind and considerate of the people, and every possible comfort is given to them. While there we had the privilege of baptizing ten new members, which swells our ranks to more than two hundred in this home of the unfortunates. The Gospel there is doing much for the people, and we have every reason to be proud of the work our people are doing. ${ }^{5}$

After returning home to Utah in the spring of 1904, William married Olivia Sessions in the Salt Lake Temple that same fall. ${ }^{6}$ Olivia, whose roots were also in Bountiful, Utah, recalled that they had actually met before William's mission call in February 19oo, when she was a seventeen-year-old student in a local Sunday school class he taught, though William was five years older. When William went on his mission, she became the teacher, and they wrote each other during his four-year mission. Soon after their marriage they left for Iosepa, 75 miles west of Salt Lake City, Utah, which was then the gathering place 
for Mormon Polynesians. William taught school there. ${ }^{7}$ Three years later he was also asked by LDS Church president Joseph F. Smith to manage the Iosepa Agricultural and Stock company. Thus, his life continued among Hawaiian people even after he returned from his mission. ${ }^{8}$

\section{As Lā'ie Temple Dedication Draws Near, Waddoups Visits Settlement}

In late 1918, William was called as the first Lā'ie Hawai'i Temple president and began to make preparations for the temple dedication, which occurred the following year on Thanksgiving Day, 1919. About this same time, the Hawaiians at Iosepa migrated back to their island homeland, now keenly aware that a temple would be erected in Lā'ie. During the summer of 1919 , William also returned to make a change in the Kalaupapa LDS Branch leadership and to involve church members in preparations for the new temple prior to the dedication. Entries from Waddoups's own journal record his activities:

Thursday July 31 st 1919 Steamed into the little bay at Kalaupapa about 7 a.m. Found Brother John M. Bright, Eleakala Naula and other saints on the wharf to see me they did not know however that I was coming. They took me to visitors quarters and I introduced myself to Dr. Goodhue in charge during the absence of Superintendent McVeigh. He received me kindly, and I was given full possession of Mr. McVeigh's home. I partook of a good breakfast-prepared by Mr. McVeigh's cook. John Bright and I did a little visiting at the Hospitals and homes prepared by the Board of Health for Lepers. I find everything clean and sanitary, the board seems to have provided all they can to make things comfortable and pleasant-for the people stationed here. At 4 P.M. we met a good number of saints at the Church and held a good spirited meeting. The good saints here seem overjoyed for $[$ sic $]$ have someone visit them. In the evening at the invitation of Dr. Goodhue I went to the hall and saw a good picture show and heard some good music.

Saturday August 2nd 1919. Brother John M. Bright having prepared two saddle horses for us we went down to Kalawao to visit the few saints who are there and also to look around through the Baldwin Home for boys. We find everything kept- up in a clean sanitary wholesome way. ... 
In the evening 6:30 we held a Priesthood meeting at which Kauhi the president of the branch was released together with his counselors; and John M. Bright was selected to fill the vacancy with Eleakala Nahulu and Abraham S. Puaniani as first and second counselors. . . . All in all I have spent a pleasant and profitable day and feel happy and proud that I am here and have the honor to represent so noble a cause. . . .

Sunday Aug 3rd 1919 After a good breakfast I went down to the church for our Sabbath meetings. Sunday School convened at 9 A.M. and there were 60 in attendance. About 10:30 our general meeting convened at which Bro Nahulu presided. Our first business was to ask for the release of retiring President Kauhi, which was sustained by a unanimous vote. The Names of the new President and councilors were presented and unanimously sustained as in the priesthood meeting the previous evening. I then set them apart for their respective positions. I then occupied the time in preaching to the people. The spirit of God was present in rich abundance and we had a pleasant and I feel profitable time. ${ }^{9}$

Waddoups's trip was published in an LDS periodical, which related his efforts to instruct the faithful Kalaupapa Saints on preparing their ancestors' names for proxy work in the Lā'ie Hawai'i Temple. ${ }^{10}$ On this same day (August 3, 1919), Waddoups set apart John M. Bright as the president of the Kalaupapa Branch, which position Bright held until $1925 .{ }^{11}$ Waddoups arrived in Hawai'i in May 1918 and spent the next 19 months promoting genealogy in Hawai'i for proxy ordinance work prior to the Lā'ie Hawai'i Temple dedication in November $1919 .{ }^{12}$ The article also noted that most, but not all of the branch members had the disease. For example, the newly sustained branch president, John M. Bright, free of the malady, was living at the settlement to take care of his wife, who was a patient. ${ }^{13}$

Waddoups, an avid genealogist throughout his life, ${ }^{14}$ eagerly shared his expertise with the Mormon congregation at Kalaupapa and others who expressed an interest in their family history. As his calling to serve as temple president drew near, he anticipated helping the Kalaupapa Branch members by having the proxy work performed for their kindred dead when the temple opened in late November $1919 .{ }^{15}$ In another journal entry, Waddoups recorded his visit with the LDS Women's organization, the Relief Society, as well as the Kalaupapa Saints in general: 
Friday August 1, 1919. At 9 A.M. attended Relief Society and enjoyed an excellent spirit. The Relief Society gave me \$30.oo for traveling expenses and $\$ 10.00$ for Temple fund. In the evening we held a meeting in the meeting house in which I instructed the saints upon temple work and the proper way to prepare their genealogies for temple work. The interest of the saints in this matter is very encouraging and we have great hopes for the work. All are very anxiously waiting for the dedication and the commencement of the work. ${ }^{16}$

The financial contributions and efforts of the Kalaupapa LDS Church members to prepare names for proxy work in the temple are even more admirable when one considers that because of the restrictions placed upon them by the Board of Health, they would not be able to attend the temple dedication or perform the proxy work for their ancestors.

The temple dedication occurred on Thanksgiving, November 27, 1919. Hundreds of Latter-day Saints from the Hawaiian Islands gathered for this sacred occasion. The dedicatory prayer, offered by the president of The Church of Jesus Christ of Latter-day Saints, Heber J. Grant, mentioned Jonathan Napela, who had passed on 40 years earlier while serving as the president of the Kalaupapa LDS branch: "We thank Thee for raising up Thy servant Elder J. H. [Hawai'i] Napela, that devoted Hawaiian."17

For Napela and other Mormons at Kalaupapa and elsewhere, death was not a finality. The temple was the intersection of heaven and earth, the place where proxy baptisms for the dead could be performed, and the location where eternal marriages for both the living and the dead were also solemnized by proxy work. ${ }^{18}$ Although the Kalaupapa Latter-day Saints couldn't participate in these sacred ordinances at that time, they faithfully prepared names for those who could attend the temple and complete the vicarious work, which is why Waddoups went to Kalaupapa for this important genealogical training. Their diligence in preparing names for temple work bespeaks their sincere belief in the LDS doctrine of vicarious work for the dead. In a report from an LDS mission conference, their enthusiasm for doing spiritual work is manifest:

"KALAUPAPA BRANCH: . . J John M. Bright, Pres., Kalaupapa, Molokai. The people here, although not allowed to mingle with the 
outside world, are taking hold of the work of the Lord and are doing all in their power to push it on. . . The Elders once or twice a year take a trip to the settlement." 19

Another article in the spring noted some challenges the Kalaupapa LDS Church members were encountering as they continued preparing names for submission to the Là'ie Hawai'i Temple:

The work of the Lord is making good progress among this unfortunate people, although not without opposition, as Satan is working hard among the people of this ... settlement and is causing some to leave the Church, while at the same time converts are being made. President Bright writes that they are not discouraged, but that their faith in the work of the Lord is growing stronger. ${ }^{20}$

\section{Report that the Mormon Congregation WAS IN GOOD CONDITION}

Over the next decade, various reports detailing the activities and condition of the Kalaupapa Saints would be recorded. For example, several LDS men received the priesthood and were advanced in various ecclesiastical priesthood offices. ${ }^{21}$ In the spring of 1927 , President Waddoups, then serving simultaneously as the Lā'ie Hawai'i Temple president and as the LDS Hawaiian Mission president, made another trip to Kalaupapa with his wife Olivia and a fellow LDS church member named Freda Linnebach: "While there Pres. William M. Waddoups dedicated the chapel, which had been remodeled and repainted. He reported that the branch was in very good condition, and large crowds attended all of the meetings." Such visits were not forgotten by the Kalaupapa Saints. ${ }^{22}$

\section{Attendance of LDS Church Members in the 1930 S}

Three years later, as the new decade of the 193 os dawned, Waddoups again visited the settlement with Olivia and their friend Freda Linnebach. After returning from this experience, he wrote an article for a LDS Church periodical to try to capture the unique spirit of the Kalaupapa settlement. Here he described that one would find a people "cheerfully hopeful, and spiritually exalted above most fellows." 
Waddoups added, "I have never known more optimistic resignation. Where you would naturally expect sadness, you find cheerfulness. Where you would look for tears you find laughter. I think I saw more smiles to the square inch in this unique village than in any other I have ever visited."

He added that the Kalaupapa Saints were among the "best tithe payers." Also, "One of the best pleasing features of our meetings with them is the singing. In no place in the world have I heard singing of such a sweet harmony, perfect rhythm, and natural soulful rendition as we heard there." ${ }^{23}$ A dozen years later, William and Olivia would return to live among the Saints of Kalaupapa as well as the entire community.

\section{William Appointed Superintendent of Kalaupapa (DECEMBER 1943-JUNE 1947)}

After a precarious mule ride down the Kalaupapa pali trail on the first day of December $1943,{ }^{24}$ William and Olivia began a three-and-a-half year assignment at Kalaupapa, where William would serve as superintendent of the settlement for a period of three-and a-half-years. In his journal, Waddoups described his appointment:

The latter part of November 1943 I was offered the position of Superintendent of Kalaupapa Leper Settlement. After due consideration, and consultation with my family and close friends we decided to accept the position. My duties to begin December 1 st. We left Honolulu by plane November 3 oth. We reached Kalaupapa the same afternoon we were received and introduced by Harry A. Kluegel, Superintendent Board of Hospitals and Settlement, and now begins a new and very different chapter in our lives. ${ }^{25}$

In his own personal history, Waddoups recounted this appointment and added that he and Olivia had "a comfortable home with servants." ${ }^{26}$ Jessie Elliot, a former secretary of William, visited Will and Olivia at the settlement and described Kalaupapa as a "little village, ... the epitome of peace and calmness and restfulness." Jesse also noted, "The supt's [Waddoups's] home is surrounded with beautiful shrubs, plants and flowers of all kinds, ... a and they have a wonderful vegetable garden with just everything growing." 27 
Concerning his salary, William recalled, "Our salary begins at $\$ 388$.oo and full maintenance with annual increments to $\$ 45^{\text {o.oo per }}$ month. December or rather Jan. 1, 1944 my salary was increased to $\$ 416.00$ with $\$ 5$ o.oo bonus per month. I resigned as Superintendent of Kalaupapa to take effect as of June 4, 1947."28

\section{General Responsibilities of Superintendent Waddoups}

Having worked at his new assignment for only one month, William wrote in his first journal entry for the year 1944, "Olivia and I are both well and happy at the beginning of a new year. We are beginning to understand some of the duties imposed on us in our new work here in Kalaupapa. We enjoy the work and find a satisfaction in the work we are doing." ${ }^{29}$

During these years of toilsome service, Superintendent Waddoups was busy overseeing a variety of tasks. His daily routine and general responsibilities are captured by several journal entries: "There is always a certain sameness about my daily programme. There are the same tasks to be performed every day, yet there are enough new jobs to keep the work interesting. Our patients homes must be looked after [and] necessary repairs made. All our mechanical equipment checked and kept in good order. Our water, livestock etc cared for." ${ }^{30}$ About six months later, Waddoups wrote, "Our usual activities are being taken care of each day. I try to keep in close touch with the four unit homes and the hospital, and to know what the needs individually and collectively are. We have our patient workers, our carpenter, plumbing, painting, electrical, laundry and mechanical departments functioning well." ${ }^{11}$ William was also involved in negotiating repairs for the Kalaupapa airport runway during his tenure: "Work has commenced, by the Army on the airport. A gang of six and seven men are now at work there. . . It is estimated, by their foreman that it will require about three weeks to put the airfield in the condition it was in before the war." 32

\section{Olivia Connects with the Kalaupapa Community}

Olivia kept herself busy connecting with the community, which included Girl Scout meetings ${ }^{33}$ as well as providing the patients with 
"instruction in old time square dances." ${ }^{34}$ Olivia and William were also very active in their own Mormon congregation at Kalaupapa. LDS Church minutes make clear that they shared their testimonies, gave lectures, and offered prayers in various Church meetings. ${ }^{35}$ Olivia's account of an Easter egg hunt captures a tender moment when one blind LDS woman was hunting for eggs following a church meeting:

After Sunday School was over the Supt. announced there would be an Easter Egg Hunting Contest, and it was an interesting surprise to me. Some of them blind, some whose feet were so bad they could hardly walk, others whose hands are so bad they could not pick up the egg when they found it. But those who needed help would call out, and others would cease their hunting and go and help the others. One of the blind Ladies Sister Manuola found four eggs, with her cane she would carefully feel around, and her glee at finding one was worth all the eggs in the country. They had a good supply of eggs and made it worth while for their fun. I was thrilled, that handicapped as they are, they laugh and enjoy things. It is remarkable the way they all help each other, they are so very kind to the blind and crippled and so patient. ${ }^{36}$

Another Easter, Olivia explained how Will "beautifully explained the 'Resurrection'" during a Sunday school lesson and mentioned her role in passing out eggs to the children. ${ }^{37}$ On another occasion she described a short Mother's Day Church program which, she noted, "Was a sad one, as none of the Saints can visit their mothers nor send anything out to them." 38

\section{Journal Entries Reveal a Close Relationship With the SetTlement}

A series of journal entries during William's term as resident superintendent demonstrate his steady involvement with the Mormon congregation at Kalaupapa. In addition, William and Olivia's spiritual depth and positive attitude are also evident in their warm and active relationship with the entire community, attested by a number of select entries from William's journal:

Sunday, Jan. 2, 1944-Today is our fast Sunday. I gave \$2.0o to [Jonah] Mahelona our branch president to help in defraying the expenses of 
the branch. I attended Priesthood meeting at 8:30. This was followed by Sunday School and then sacrament meeting. The people seem to enjoy having us in their meetings, and we enjoy taking part with them...

Sunday, Jan. 23, 1944 — . . I attended Priesthood meeting in the Kalaupapa chapel. Our attendance is small but our people are sincere. Olivia came down at 9:30 and together we attended Sunday School. We take our own bread and water and partake of the sacrament with the rest of the saints. Our classes in Sunday School are simple and not according to the patern $[s i c]$ in larger schools but it is sincere worship. Our regular Sabbath service follows Sunday School. Today it was conducted by the branch genealogical officers. Olivia and I were both asked to speak....

Tuesday, Feb. 8, 1944-Today is my Sixty Sixth birthday. . . The members of the church here came to the house at noon, stood outside the gate and serenaded us with Hawaiian songs. Jack Sing and wife sent a lovely boquet (sic) of roses and ferns. The Catholic sisters of Bishop Home sent a bunch of orchids and a box of luscious tomatoes. I felt very much honoured by the expressions of good will. . . Father Peter of the Catholic Church has come to our home and paid his respects....

Sunday Dec. 10, 1944-I attended Sunday School at 9 a.m. I met with the English Senior class, we discussed the Priesthood quorum and Welfare organization of the church. . . O Our group is small, but they are sincere Latter-day Saints. ${ }^{39}$

Sunday Jan. 14, 1945-We attended our regular Sunday services today. Sunday School at 9 a.m. Church service at 10 a.m. followed by Priesthood meeting. Olivia and I were asked to report on our trip to Honolulu for the New Year season. ... Olivia and I attended a meeting of the Boy and Girl Scouts.

Thursday Feb. 8, 1945-Today is my 67 th birthday. . . . The Catholic Sisters came in and brought me some flowers. Jack Sing brought a lei for my hat. He is our general foreman. . . . I am most thankful that I have reached my 67 th year in such good health and circumstances. I indeed have many things to be grateful for. God has been kind to me.

Sunday Feb. 18, 1945- . . I attended Priesthood meeting, Sunday School and general Church services. Many of our people have colds and other ills, so our attendance was small, but we have a good spirit present and I enjoyed the meetings. 
Sunday Mar. 1 1,1945-Olivia and I attended Sunday School and general meeting. Our attendance was small as a good number of our members are unable to attend. I was asked to report my trip to Honolulu. Our people here are always happy to get reports from the outside.

Sunday Mar. 18, 1945-I attended Sunday School and general Church meetings. Our attendance was small. We attended a gathering of the Boy Scouts honoring Harold Stein. Our newly organized orchestra made their first appearance. Their playing was creditable. The Girl Scouts sang several numbers.

Sunday Apr. 1, 1945-Today is Easter Sunday. It is also our regular fast day. . . After an enjoyable programme the children were dismissed to search for nine dozen eggs hidden in various places on the grounds of the Church. Most, if not all found some eggs.

Sunday Apr. 22, 1945-We enjoy meeting with our small group and partaking of the sacrament. Our general meeting after Sunday School is very poorly attended. Most of the members go to the homes where they live for lunch which is served about 11 a.m.

Sunday Apr. 29, 1945-We went to Sunday School. The sacrament is administered in Sunday School. General meeting follows immediately after Sunday School. . . . Our attendance is small but we have a good spirit present and we have good times together.

Sunday June 24, 1945-I attended Sunday School and general meetings. Albert Kahina and Henry Kaahanui from Hoolehua visited us today as missionaries. We enjoyed having them with us. They gave talks encouraging the people. ${ }^{40}$

Sunday July 1, 1945-We enjoyed partaking of the sacrament and worshipping with our patient saints. After church we spent the day at home reading. . . . I gave $2^{\text {oo }}$ to Mahelona, president of our branch to help pay branch expenses.

Saturday July 7, 1945-Olivia and I attended a camp fire jamboree with the Boy Scouts at Kalawao in the evening.

Tuesday July 1 7, 1945-Olivia and I drove down to Kalawao. I went down to Kalawao. I went down to inspect our Boy Scout Camp. The boys keep their camp clean and orderly.

Sunday July 22, 1945-I attended Sunday School and assisted in the Senior class in discussing amusements and recreation. In the general 
meeting I was asked to speak on the meaning of great image which Nebuchadnezzar saw, as recorded in Daniel chapter 2.

Tuesday July 24, 1945-Today is the 98th anniversary of the arrival of Brigham Young and his pioneer band in the Great Salt Lake Valley. . . . I wrote letters to Pres George Albert Smith, Joseph Fielding Smith . . . [and] I visited the Boy Scout camp at Kalawao. ${ }^{41}$

Sunday July 29, 1945-Olivia and I attended Sunday School and church Services. In Sunday School we considered the Church and the future life. There were some interesting comments.... I and Olivia were asked to speak briefly on ... Pioneer Day. ${ }^{42}$

Sunday Sept. 16, 1945-I attended priesthood meeting, Sunday School and general Church service. I was asked to report on our trip to Honolulu. ${ }^{43}$

Sunday Oct. 14, 1945-We attended Sunday School and church. We partook of the sacrament and took part in exercises and discussions of the meetings. We held forth in the hall today, as our meeting house is being painted. At 1 P.M. today a series of soft ball games began. I batted out the first ball. I am not in favor of Sunday sports, but it is the desire of the people and has been so conducted for years. I do not feel authorized to change it. ${ }^{44}$

The $5^{2}$ names listed on the LDS Church tithing list for $1945 \mathrm{docu}-$ ment a clear Mormon presence during the Waddoups's era. ${ }^{45}$ However, poor health and other challenges seem to have played a role in Church activity; Olivia Waddoups described a much smaller (though grateful) number of Saints gathered for a Sunday Church meeting the following year:

We attended the Services at the Church there were 19 to Sunday School and 9 at meeting, among these 9 was one blind man, two with tubes in their throats, three of them with only one eye, rather a pathetic picture but they expressed only gratitude and thanks for the many blessings they receive. ${ }^{46}$

Although Olivia and William were affiliated with the Latter-day Saints, they continually took time to be intimately involved with the larger Kalaupapa community. It appears that Olivia was particularly impressed with the compassionate service given by the patients to 
others outside the settlement. For example, one noteworthy event was a clothing drive the patients sponsored to aid needy patients at the Culion leprosy settlement in the Philippines. Olivia wrote, "I am awe stricken at the vast collection of very nice clothes, shoes, sneakers, coats, and undies, pajamas and other things that the Patients have brought." 47

\section{Festive Ecumenical Celebrations at Kalaupapa}

On Christmas Eve of 1945, William recorded a journal entry which reveals the ecumenical nature of the Kalaupapa community, especially at Christmas time:

Our church people held a Christmas service this evening at 6:30. I was asked to be the speaker. Some members of the congregational church attended our service and sang two songs. We had a good crowd, the church was well decorated, the tree was beautiful. At 11:30 p.m. I attended the service at the congregational church. They had a candle lighting service which was beautiful. I was asked to offer the prayer. Dr. Norman Sloan delivered the sermon. The service lasted until about 1 a.m. I attended the Catholic midnight Mass for a short time. All the church buildings and yards were specially lighted with colored lights. Kalaupapa is very colorful for the Christmas season. Few grasp the real meaning of Christ's birth and mission. ${ }^{48}$

The following year, William again reported the holiday season when the whole community once more held festive events. In these activities, "all the churches observed suitable and impressive services, . . . [and] all the church buildings and yards were artistically decorated and lighted." On New Year's Eve, a visiting seven-piece orchestra "furnished very good music for the dance." ${ }^{49}$ In his final year of serving as superintendent, Waddoups was asked to deliver a sermon for the Protestants' Easter-morning service. One visitor in attendance recalled that it was a "very beautiful sermon" coupled with "beautiful music." The guest further noted, "Their organist is a patient, hands were stubbs, [sic] but he made the organ ring." ${ }_{50}$

In spite of the challenging times caused by the debilitating disease during the 1940s, Nancy Talino recalled that in the settlement, "there was always music. People were always singing. I think that's one of the 
things that kept everybody happy, when you get together and sing together." 51 The Waddoupses supplemented the music they heard at the settlement by listening to the Sunday broadcasts of the Mormon Tabernacle Choir on their home radio. ${ }^{52}$

\section{Times Of Diversion and Spiritual Renewal}

William and Olivia made time for needed diversion, which included trips to Honolulu. ${ }^{53}$ In addition, they took daily walks on the beach, attended weekly movies, played Rook, read books with close friends, and enjoyed quiet evenings alone in their home. ${ }^{54}$ Further, they prayed and fasted regularly to draw strength for carrying out their demanding duties. The following journal entry provides a glimpse into their spiritual depth and recognized need for divine power:

Olivia and I are fasting today. I find much spiritual and physical strength through fasting and prayer. Separated here as we are, from associations with larger branches and church leadership and activities, we need some help and physical strength to carry on our work. We associate every day, and most working hours with people who suffer with this dread disease Leprosy. I feel that we need some source of additional strength to keep us on an even physical, spiritual and mental keel. God has been kind and merciful to me..$^{55}$

A year after their arrival, William and Olivia attended a movie at Paschoal Hall titled Pack Up Your Troubles. This film apparently triggered an emotional surge of homesickness in the Waddoupses. Will wrote tenderly, "We look forward with longing to the time when we can return to our old home in Utah. Many of us are growing old and I feel that we should have a reunion with our loved ones before too long or some of our members may be taken away before we see them. We are torn by two loves, our children here and our loved ones in the mainland. We cannot be in both places, of course." He added, "We want to be near a temple always." ${ }_{56}$

In another entry written seven months later, William explained, "I enjoy the work here. It is not very burdensome. Our home is comfortable, our help is good and well prepared, my salary is by far the greatest I have ever had, and our expense is so little." He added, "The 
things we miss is our Church contacts, the thing we have spent our life at, and which is most dear to us. As soon as our finances will permit, we plan to return to Salt Lake City and again take up our church activities. ${ }^{57}$

\section{Tsunami Strikes Hawai'i and the Kalaupapa Settlement}

An unexpected tidal wave reached the flat Kalaupapa peninsula on April 1, 1946. A 7.4 magnitude earthquake, deep in the Aleutian Island Chain, spawned a fierce Pacific-wide tsunami that struck the flat Kalaupapa peninsula, causing serious damage. ${ }^{58}$ Thankfully, no one was killed on Kalaupapa; however, "twelve beach homes were washed away and others damaged. Cemeteries along the shore were a shambles, with massive gravestones moved off their foundations, and fences and stone walls destroyed." ${ }^{59}$

Some of the Kalaupapa community thought the warnings were a joke, because the tsunami occurred on April Fools' Day. ${ }^{60}$ Henry Kalalahilimoku Nalā‘ielua remembered, "On April Fool's Day 1946, my roommate Nicky Ramos woke me up at 6:35 a.m. 'Eh!' he said, looking out the window. 'Somet'ing wrong with da water.' 'What?' I jumped out of bed ... pretty soon a whole beach house floated by. ... The waves must have been 35 or 4 o feet high. Huge!" 61

Olivia recorded this memorable day when her husband's life was miraculously spared:

The ocean then was rising and it came up so fast and oh so high and with such force we all ran, but Will who had gone to move his car, thinking the waves would not reach us. But before he could get in the car, the force of the water had banged the door against him, throw [ing] a large truck against his car. How he was extricated out, God knows; he was badly bruised, then washed and hurled with the water about 20 feethead over heels and striving to save himself hurt as he was, then he saw me floundering in the flood of water against a rock wall. I was hurled from my feet-rolled over several times, and I put my arms around a coconut tree, realizing the back wash would be terrific, I thought to save myself. But was suddenly covered with water and a force that sent me about fifteen feet against the rock wall. One of the men Renaldo saw me and came to help, for fear I would drown, the water receded $[s i c]$ some and we got over the rock wall. ... Will was suffering such 
pain, we got him home and the Dr. came and examinations and xrays now show there are no broken bones but he is very badly crushed and bruised thru the center of his body. O what a mirical [sic] he was not killed. We are so very thankful for his life. ${ }^{62}$

Olivia also described the destruction these fierce waves caused to the general landscape of the settlement:

I have no words to explain the havoc and destruction we have here [at] Wills office and the Post Office a large three office building was whirled off its foundation and turned half way around. many beach homes flattened, some washed out to sea, pig-pens \& chicken coops, fences and garages washed away. One home a large dwelling was washed out standing up but, soon all we could see was the roof as it floated away in the ocean. Our cemetery was terribly damaged, had stones, slabs of cement, cement pillars of the gateways were scrapped off and floated several hundred feet, fishes left out on the land and our water system about $15^{\text {oo feet }}$ of pipe line near the intake has thrown us into a serious water shortage. ${ }^{63}$

Notwithstanding, Waddoups's body was eventually restored to full health, buildings were repaired or rebuilt, and normalcy was restored to the community.

\section{Lds Apostles Visit Kalaupapa During THE WADdoup's TenuRE}

In late July of this same year, William and Olivia felt fortunate to host an LDS dignitary, Apostle Spencer W. Kimball, his wife Camilla, as well as Sister Cowley, wife of Matthew Cowley, also an Apostle of the LDS Church. ${ }^{64}$ Elder Cowley carried the tremendous responsibility of overseeing tens of thousands of Church members across the Pacific. He was greatly loved by the island people and affectionately known as the "Polynesian Apostle." Kalaupapa was part of his stewardship in the Pacific region, and he took the time to visit the Latter-day Saints in their secluded settlement. One of the LDS patients, Jack Sing, remembering Cowley's visit, remarked that he was "a very jolly man. . . . He talk, lot of fun and saluting us and all that. Now he's a fine fellow." ${ }^{65}$

Olivia recorded in her journal the experience of Elder Cowley's 
visit the following year on March 27, 1947: "Bro. Cowley, Jenkins \& Clissold came. ... We then all went to meeting where the Brethren gave some splendid advice. .. Bro. Cowley pleased me then with his Maori language and chants and then a very spiritual talk. ... We feel very honored and humble in this great privilege. We feel we have had a very special day." ${ }^{66}$

Elder Cowley was likewise humbled and touched by this Kalaupapa encounter, which he later recalled when speaking at an LDS Tongan Mission conference held not long thereafter:

I thought when I looked at those people I would feel very sad, but when I looked my soul was lifted up and they all looked like holy people to me. Another song they sang was "Count Your Many Blessings" and there those people are to stay the rest of their lives and will never go home-and yet they can sing these songs with joy and happiness in their hearts. They have love in their hearts for the Church and for the Gospel. $^{67}$

Although Elder Cowley's visit to the settlement lasted only a few hours, the community of Kalaupapa made a profound impression upon him, as evidenced in a letter of gratitude he sent to the Waddoupses:

To you and Sister Waddoups I hasten to send my aloha and mahalonui for a few hours of genuine inspiration spent at Kalaupapa, and for the kind hospitality of your lovely home. The visit was all too short, yet it will be vivid upon my memory forever. I went there apprehending that I would be depressed. I left knowing that I had been exalted. I had expected that my heart, which is not too strong, would be torn with sympathy, but I went away feeling that it had been healed. . . . I went from the meeting appreciating my friends, loving my enemies, worshiping God, and with a heart purged of all pettiness. This is a transformation for me and for it, I am indebted to the leper Saints of Kalaupapa. ${ }^{68}$

\section{William Retires, Waddoupses Return Home, But Do Not Forget Patients}

The Waddoupses, also deeply influenced by their Kalaupapa experience, continued their diligent service in the settlement until the end of May 1947, when William reached his seventieth year and retired. ${ }^{69}$ 
Former Hawai'i territorial governor Lawrence M. Judd then became the new superintendent, and Will and Olivia returned to Utah. ${ }^{70}$ In a final monthly report as superintendent, he noted, "All the medical Staff have been very cooperative, and our association has been most pleasant. . . . I commend all the patients for their patience with me and for their good will and cooperation. . . My work has been a pleasure and a fine experience." 71 The patients expressed their love to William and Olivia by presenting them with a beautiful set of sterling silver utensils before their departure. ${ }^{72}$

William could not forget his friends at Kalaupapa. Two years after Waddoups was released as superintendent, he sent a letter to Elder David Hannemann, an LDS missionary assigned to Kalaupapa: "Please give our alohanui to our dear friends there. We can never forget them and the association which we had with them. Those are precious memories we cherish." ${ }^{33}$ William passed away in $195^{6}$; seven years later, Olivia, though 8 o years of age, made the effort to once again to visit the patients at the settlement. Reflecting on her Kalaupapa experience several years later she said, "If there is any people on earth who truly love their neighbor as themselves, it's those people."74 Reflecting back on the selfless service William rendered spanning decades and the collective charitable contribution made by the Waddoupses during several administrative years, surely the Kalaupapa community also felt this same way about William and Olivia. ${ }^{75}$

\section{Notes}

1 "Personal History of William Mark Waddoups," 3, courtesy of Sarah E. Hale, a great-granddaughter of Waddoups (sent to the author via email January 2, 2016), hereafter cited as PHWMW.

2 PHWMW, 3.

${ }^{3}$ PHWMW, 3-4. His mission president was Samuel E. Woolley, who later provided temporary food for the patients at Kalaupapa during a food shortage.

${ }^{4}$ There were 968 patients at Kalaupapa in 1904 . See R. C. Schmitt, Historical Statistics of Hawai'i (Honolulu, Hawai'i: University of Hawai'i Press, 1977), 72. Thanks to Hawai'i State archivist Jason Achiu for his help with statistics.

5 “Mormon Elders' Work in a Leper Settlement," Deseret Evening News, June 4, 1904, 7. See also Latter-day Saints' Millennial Star, June 23, 1904, 391. Samuel Woolley, LDS mission president and plantation manager in Lā'ie, wrote in his journal of this event, "Wednesday April 271904 I was busy at the house all forenoon chatting with Bros. Waddoups and Johnson about their Kalaupapa trip. 
They dedicated a meeting house at Kalawao Sunday morning the 24th inst and one at Kalaupapa the same day the two settlements gave a feast. They Baptized 10 new members and blessed 3 children while there and had a Jolly good time. The people are all feeling fine and are happy and contented, and are treated fine, by the Superintendent Mr McVaie [Jack D. McVeigh]." Samuel E. Woolley, Journals, April 27, 1904, typescript in possession of author. LDS Church records written in Hawaiian from this era also confirm that gospel study was being conducted on a regular basis, which no doubt contributed to the spiritual stability, happiness, and peace of the congregation. Many accounts provide notations of scriptural texts being discussed weekly. See Kalaupapa Branch daily program of Kalaupapa Sunday School, 1911-1918, Kalaupapa Branch, Hawai' $i$ Mission, LR 4289 21, Church History Library, Salt Lake City, Utah.

${ }^{6}$ They were married October 1 2, 1904, by Elder John R. Winder. See PHWMW, 4 .

${ }^{7}$ Dorothy O. Rea, "Thou Shalt Love Thy Neighbor as Thyself," Church News, July 9, 1966, 11. For more information on Iosepa, see Matthew Kester, Remembering Iosepa: History, Place, and Religion in the American West (New York: Oxford University Press, 2013); Dennis H. Atkin, "A History of Iosepa, the Utah Polynesian Colony" (master's thesis, 1959, Brigham Young University); Dennis H. Atkin, "Iosepa: A Utah Home for Polynesians," in Voyages of Faith: Explorations in Mormon Pacific History, ed. Grant Underwood (Provo, Utah: Brigham Young University, 2000), 71-88; Tracey E. Panek, "Life at Iosepa, Utah's Polynesian Colony," in Proclamation to the People: Nineteenth-Century Mormonism and the Pacific Basin Frontier, ed. Laurie Maffly-Kipp and Reid L. Neilson (Salt Lake City: University of Utah Press, 2008), $170-181$.

8 PHWMW, 4 .

${ }^{9}$ William Waddoups, journal, July 31 and August 2-3, 1919. A hui opio was an LDS meeting for young people, known in English as the Mutual Improvement Association, or simply the MIA.

${ }^{10}$ Reference to proxy work means performing vicarious temple work such as baptism and other sacred ordinances for ancestors who are deceased.

${ }^{11}$ Date noted in a copy of an LDS Ledger in possession of author.

12 "Hawaiian Mission. Kalaupapa Branch," Liahona, the Elders Journal 17, no. 10 (November 11, 1919): 164. The author thanks Riley Moffat for calling attention to this issue the length of time that Waddoups spent preparing the Kalaupapa Saints for temple ordinance work prior to his calling as a temple president.

13 John M. Bright was listed as a part Hawaiian kokua (helper) to "Mrs. Bright" from Honolulu, who entered the settlement on September 9, 1918. See Kalawao Kokuas I968 to I929. See series “26o Hansen’s Disease," vol. 10, Health / Comm. Dis, AH, Honolulu. An LDS record notes, "Sister J. M. Bright was born December 10, 1866. See 1916 LDS Church “Teachers Record," Box 2, Folder 1, Kuulei Bell Collection, MSSH, 561, Brigham Young University-Hawai' $\mathrm{i}$ Archives and Special Collection, Lā'ie, Hawai'i.

${ }^{14}$ That Waddoups was heavily involved in genealogy and temple work is attested 
by journal entries that provide compilations of the numbers of people who had received temple ordinances over the years. Further, at the back of William's 1946 journal, there are notations about temple ordinances as late as December 1955. Further, after these notations, there is a note by Olivia: "Feb. 11 th, 1957. I am recording the last of the Sealings Bro Waddoups performed in the Salt Lake Temple." See also Ethel Damon, Siloama: The Church of the Healing Spring, (Honolulu: Hawaiian Board of Missions, 1948) 34. Here, Damon further notes, "I had the pleasure of visiting with Mr. and Mrs. Waddoups in their home at the Settlement, and of seeing there the long Polynesian genealogies which Mr. Waddoups has compiled during a lifetime of service in the Pacific area."

${ }^{15}$ Waddoups served as the president of the Lā'ie Hawai'i Temple from 1919 to 1930. He also served as the LDS president of the Hawai'i Mission from 192631.

${ }^{16}$ William Waddoups, Journal, August 1, 1919. Two and a half years earlier, there is evidence that as early as February 1917 , Kalaupapa Saints were giving $\$ 5$.oo donations to the La' ie Hawai'i Temple Fund, even though the temple would not be dedicated until November 1919. See "Tithing and Temple Fund Report for the month ending Feb. 28th 1919," Kalaupapa Records, Kalaupapa/Kalawao Collection, Box 2.

${ }^{17}$ Manuscript history of the Hawaiian Mission, BYU-Hawai'i Special Archives, hereafter cited as MHHM, November 27, 1919. For more information on the life of Jonathan H. Napela, see Fred Woods, "A Most Influential Mormon Islander: Jonathan Hawai'i Napela," HJH 42 (2008): 135-57; Fred E. Woods, "An Islander's View of a Desert Kingdom: Jonathan Napela Recounts his 1869 Visit to Salt Lake City," BYU Studies 45, no. 1 (2006): 23-34; Fred E. Woods, "Jonathan Napela: A Noble Hawaiian Convert," Regional Studies in Latter-day Saint Church History: The Pacific Isles, ed. Reid L. Neilson et al. (Provo, Utah: Religious Studies Center, 2008): 23-36.

18 These doctrinal beliefs about the temple stem from an LDS interpretation of biblical passages. For example, Mormons believe that when the Apostle Paul asked, "What shall they do which are baptized for the dead, if the dead rise not at all?" Paul was referring to the doctrine of baptizing in proxy for the dead who had not yet been baptized, or had not been baptized by proper priesthood authority (see 1 Corinthians 15:29). Further, Latter-day Saints believe that when Jesus said to Peter, "I will give unto thee the keys of heaven: and whatsoever thou shalt bind on earth shall be bound in heaven," Jesus was referring to a priesthood sealing power, which included uniting a man and woman in marriage not just until "death do they part," but for time and all eternity (see Matthew 16:19). Interestingly, when Jonathan Napela returned from his visit to Salt Lake City in the late fall of 1869 , he immediately met with King Kamehameha $\mathrm{V}$ and related the following concerning this meeting in a later letter to Brigham Young: "I informed my king that B. Young's responsibility to Kamehameha I was concluded, as I was baptized on his (Kamehameha I's) behalf; but that he (the king) is responsible for the remainder of his ancestors 
buried in the earth and that their salvation rests upon him and that he must think about them. . . There was much astonishment . . and appreciation." Jonathan Napela, letter to Brigham Young, dated April 11, 1871, translated by Jason Achiu. Concerning the rest of the visit, see Fred E. Woods, "An Islander's View of a Desert Kingdom," BYU Studies 45, no. 1 (2006): 23-34.

19 Wilford W. King, "Hawaiian Mission. Kalaupapa Branch," Liahona 17, no. 13 (December 23, 1919), 220.

${ }^{20}$ King, "Hawaiian Mission. Kalaupapa Branch," Liahona, March 16, 1920, 318 19 .

${ }^{21}$ See, for example, entries in the MHHM, September 24, 1924, and January 13, 1929 .

${ }^{22}$ MHHM, May 5, 1927.

${ }^{23}$ William M. Waddoups, "Cheer and Trust to Face Adversity," Improvement Era, August 1930, 714-15.

${ }^{24}$ Olivia noted that the trip to Kalaupapa was made by mule. See Dorothy O. Rea, "Thou Shalt Love Thy Neighbor as Thyself, Church News, July 9, 1966, 11.

${ }^{25}$ See William Waddoups, journal, 1939-1943, late November 1943, William Waddoups Journals MSS 842 1, L. Tom Perry Special Collections, Harold B. Lee Library, Brigham Young University, Provo, UT.

${ }^{26}$ PHWMW, 9.

${ }^{27}$ Elliot's visit occurred two months before the Waddoupses left Kalaupapa. See Jessie Elliot, letter, April 6, 1947, Kalaupapa/Kalawao Collection, MSSH $5^{61}$, box 6, folder 1, in Jessie Elliot Correspondence, "Easter Sunday at Kalaupapa, Molokai-1947," Donated by Clyde Hull, Joseph F. Smith Library Archives and Special Collections, BYU-Hawai'i, Lā'ie Hawai'i.

${ }^{28}$ PHWMW, 9.

${ }^{29}$ William Waddoups, journal, January 1, 1944, William Waddoups Journals, MSS 8421 , L. Tom Perry Special Collections.

${ }^{30}$ William Waddoups, journal, February ${ }^{15}, 1945$.

${ }^{31}$ William Waddoups, journal, February 15,1945 .

${ }^{32}$ William Waddoups, journal, January-March 1946, William Waddoups Papers, MS 15040 , Church History Library. In his report to the Board of Hospitals and Settlement, December 1945, p. 3, "Records Relating to Hansen's Disease. Monthly Statistical \& Narrative reports by the Superintendent of Kalaupapa, Sept 1944-July 1947," Series 260, AH.

33 Olivia Sessions Waddoups, journal, January 15, 1944, January 22, 1944, February 7, 1944, William Waddoups Papers, MS 15040, Church History Library.

34 William Waddoups, Monthly report to the Board of Hospitals and Settlement, November 1944, p. 2, "Records Relating to Hansen's Disease. Monthly Statistical \& Narrative reports by the Superintendent of Kalaupapa, Sept 1944-July 1947," Series 260, AH, notes, "Some special instruction in old time square dances is being given under the direction of Mrs. Waddoups."

35 Sacrament meeting minutes for the dates of July 30, August 6, August 20, September 3 , September 17 , October 1, November 5 , November 19, and Decem- 
ber 3, 1944, Kalaupapa Branch, Hawai'i Mission, General Minutes, LR 428911 vol. 3s, Church History Library.

${ }^{36}$ Olivia Sessions Waddoups, journal, April 9, 1946, William Waddoups Papers, MS 15040 , Church History Library.

${ }^{37}$ Olivia Sessions Waddoups, journal, April 21, 1946, William Waddoups Papers, MS 15040, Church History Library.

38 Olivia Sessions Waddoups, journal, May 12, 1946.

${ }^{39}$ William Waddoups, journal, December 10, 1944, William Waddoups Journals, MSS 8421 , L. Tom Perry Special Collections.

40 This same month, LDS missionary Wiley M. Nebeker, apparently in correspondence with his mission president, Eldred L. Waldron, wrote the following, amid several other journal excerpts: "June 13, 1944 in Company with Elders Anderson and Hunt, I went to the Kalaupapa Leper settlement. We visited with the people and held a special meeting with the Saints in the Chapel. This was one of the most inspirational meetings I have attended. A dinner was enjoyed by all at the Home of Bro. and Sister Waddoups, with Brother and sister Worley present." See "June 19, 1944 Report of Wiley M. Nebeker," LR 3695 2 1, Reel 1, Box 1, Folder 3, Church History Library.

${ }^{41}$ William was on close terms with LDS Church President George Albert Smith, as well as Joseph Fielding Smith, then serving in the LDS Quorum of the Twelve Apostles.

${ }^{42}$ Pioneer Day is an annual holiday celebrated in Utah each July 24, which (as noted above) is the day Brigham Young led a company of Latter-day Saints into the Salt Lake Valley.

${ }^{43}$ William Waddoups, journal, September 16, 1945, William Waddoups Journals, MSS 8421 , L. Tom Perry Special Collections.

${ }^{44}$ William also donated a "perpetual trophy" for the Kalaupapa softball league. See Lawrence Judd, Monthly report to the Board of Hospitals and Settlement, June 1947, pp. 7-8, "Records relating to Hansen's Disease, Monthly Statistical \& Narrative reports by the Superintendent of Kalaupapa Sept. 1944-July 1947," Series 26o, AH. The various excerpts noted above are taken from William Waddoups, journal, January 1944-October 1945, William Waddoups Journals, MSS 8421 , L. Tom Perry Special Collections.

45 Kalaupapa Branch 1945 Annual Report, Kalaupapa/Kalawao Collection, MSSH $5^{61}$, box 2, folder 1, Joseph F. Smith Library Archives and Special Collections.

${ }^{46}$ Olivia Sessions Waddoups, journal, July 28, 1946, William Waddoups Papers, MS 15040, Church History Library.

${ }^{47}$ Olivia Sessions Waddoups, journal, March 20, 1946, William Waddoups Papers, MS 15040, Church History Library.

${ }^{48}$ William Waddoups, journal, December 24, 1945, William Waddoups Journals, MSS 8421 , L. Tom Perry Special Collections.

49 William Waddoups, Monthly report to the Board of Hospitals and Settlement, December 1945, 3, in "Records relating to Hansen's Disease, Monthly Statistical \& Narrative reports by the Superintendent of Kalaupapa Sept. 1944-July 
1947," Series 26o, AH. There is also evidence of dozens of instruments at Kalaupapa during the Judd era as well as several which were to be ordered. See "List of instruments in Kalaupapa Recreation," June 2, 1948, box ${ }_{15}$, folder 221 , Lawrence M. Judd Collection, series M-42O, AH.

${ }^{50}$ Jessie Elliot, letter, April 6, 1947, Kalaupapa/Kalawao Collection, MSSH $5{ }^{61}$, box 6, folder 1, in Jessie Elliot Correspondence, "Easter Sunday at Kalaupapa, Molokai-1 1947," Donated by Clyde Hull, Joseph F. Smith Library Archives and Special Collections.

${ }^{51}$ Nancy Talino, interview by Fred E. Woods, January 9, 2009, Hale Mōhalu, HI.

${ }^{52}$ Olivia Sessions Waddoups, journal, January 9, 1944, May 26, 1946, William Waddoups Papers, MS 15040, Church History Library.

${ }^{53}$ William Waddoups, Monthly reports to the Board of Hospitals and Settlement, January 1945, March 1945, May 1945, September 1945, November 1945, February 1946, May 1946, November 1946, December 1946, "Records relating to Hansen's Disease, Monthly Statistical \& Narrative reports by the Superintendent of Kalaupapa Sept. 1944-July 1947," Series 26o, AH, evidence William made regular trips to Honolulu for work purposes or that he and Olivia took time off to vacation in Honolulu together. "Records relating to Hansen's Disease, Monthly Statistical \& Narrative reports by the Superintendent of Kalaupapa Sept. 1944-July 1947," Series 26o, AH.

54 William Waddoups, journal, January 7, 9, 16, 28; February 4, 1 1; March 14, 24, 1945. Note that the Waddoupses often met with their LDS friends Robert and Beverly Worley to discuss gospel readings or to enjoy a game of Rook. Robert was a non-patient employee at the settlement. William noted on April 27, 1945, that Worley was to be inducted into the US Army on May 21, 1945. Journal entries indicate that the Waddoupses usually attended a movie each week at the Paschoal Social Hall. In a journal entry dated January 31, 1945, William noted, "Olivia and I usually go to some part of the beach for a rest and change, after work, each day." In another entry on March 27, William wrote, "After dinner, Olivia and I spent an hour on the beach. This is about our only diversion away from our home." Many journal entries attest to these various activities throughout the year 1945. See William Waddoups Journals, 1945, MSS 8421, L. Tom Perry Special Collections.

${ }^{55}$ William Waddoups, journal, January 23, 1945, William Waddoups Journals, MSS 8421 , L. Tom Perry Special Collections. This fast was conducted on a Tuesday, rather than on the regular LDS fast scheduled the first Sunday of each month, which reveals an additional effort to draw strength.

${ }^{56}$ William Waddoups, journal, February 19, 1945, William Waddoups Journals, MSS $84_{21}^{1}$, L. Tom Perry Special Collections. At this time, the Waddoupses had grandchildren as well as two grown daughters (Miriam and Mary) living in Honolulu.

${ }^{57}$ William Waddoups, journal, September 18, 1945, William Waddoups Journals, MSS 8421 , L. Tom Perry Special Collections. 
58 “1946 Aleutian Tsunami,” USC Tsunami Research Group, http://www.usc.edu/ dept/tsunamis/alaska/1946/webpages/.

${ }^{59}$ Linda W. Greene, Exile in Paradise: The Isolation of Hawai'i's Leprosy Victims and Development of the Kalaupapa Settlement, I 865 to the Present. Branch of Planning, Alaska/Pacific Northwest/Western Team, U.S. Dept. of the Interior, National Park Service, Denver Service Center, $1985,526$.

${ }^{60}$ Danny Hashimoto, interview by Fred E. Woods, February 9, 2015 , Kalaupapa.

${ }^{61}$ Henry Kalalahilimoku Nalaielua and Sally-Jo Keala-o-Ānuenue Bowman, No Footprints in the Sand: A Memoir of Kalaupapa (Honolulu: Watermark Publishing, 2006), 53-54.

${ }^{62}$ Olivia Sessions Waddoups, journal, April 1, 1946, William Waddoups Papers, MS 15040 , Church History Library. In an interview conducted with former Kalaupapa patient Nancy Talino on March 1, 2015 at Hale Mōhalu, Nancy recalled that on that eventful day, William had been pinned to the wall by the tidal wave. However, it was in fact Olivia who had been thrown into a rock wall, while Will had been bruised by the water that banged his car door against him.

${ }^{63}$ Olivia Sessions Waddoups, journal, April 1, 1946, William Waddoups Papers. When Olivia noted the damage to the cemetery, it appears that she meant the Kalaupapa cemetery in general and not the LDS section. This observation is based on a journal entry which states, "Bro. [Jack] Sing told the story of the cemetery there when the tidal wave hit and destroyed graves on both sides, but not ours [LDS section]." This entry is followed by a drawing with the Catholic section of the cemetery on the left, the LDS in the middle and the Protestant on the right, with the following words attached: "Catholic destroyed, L.D.S. safe, Protestant destroyed.” See J. Collin Allan, journal, January 31, 1955, copy of entry in possession of author.

${ }^{64}$ Olivia Sessions Waddoups, journal, July 24, 1946, notes that Elder Spencer W. Kimball, Sister Camilla Kimball, and Sister Cowley visited the settlement nine months before Elder Cowley came. Elder Cowley was sick at the time and therefore could not come on the earlier visit. Concerning this visit, Olivia also noted the LDS patients were "truly grateful for the visit and blessing of Apostle Kimball last Wednesday." See Olivia Sessions Waddoups, Journal, July 28, 1946.

${ }^{65}$ Jack and Mary Sing, interview by Ishmael Stagner and Kenneth W. Baldridge, February 24, 1979, typescript, 6, Joseph F. Smith Library Archives and Special Collections.

${ }^{66}$ Olivia Sessions Waddoups, journal, March 27, 1947, MS 15040, William Waddoups Papers, Church History Library. Olivia also wrote on this same date, "We have appreciated the fact that three Apostles have visited us here since we came to Kalaupapa. Apostles [Harold B.] Lee, [Spencer W.] Kimball \& [Matthew] Cowley, also Sisters Kimball \& Cowley." Sister Cowley accompanied her husband, Elder Cowley, and Sister Camilla Eyring Kimball accompanied her husband Elder Kimball. Elder Spencer W. Kimball visited on July 24, 1946, and Elder Harold B. Lee visited on July 26, 1946. See Olivia Sessions Waddoups journal, July 28, 1946 and William Waddoups Journal, July 26, 1946. The author thanks 
Ardis Smith, Church History Library archivist for helping to identify the visits of these apostles. In his official superintendent's monthly report for March 1947, William Waddoups wrote, "Matthew Cowley official of Mormon Church and party [of] three visited." Records relating to Hansen's Disease, Monthly Statistical \& Narrative Reports by the Superintendent of Kalaupapa, September 1944-July 1947, Series 26o, AH.

${ }^{67}$ Elder Matthew Cowley, “Tongan Mission History,” June 22, 1947, Church History Library. These remarks were made by Cowley during the first session of the Tongan Mission conference held in the Matavaimoui chapel in Nuku'alofa, Tongatapu, Tonga. The author expresses appreciation to his friend and colleague Riley Moffat for bringing this document to his attention and transcribing it.

${ }^{68}$ Henry A. Smith, Matthew Cowley: Man of Faith (Salt Lake City: Bookcraft, 1954), 300-1. William Waddoups later gave a copy of this letter to D. Arthur Haycock,

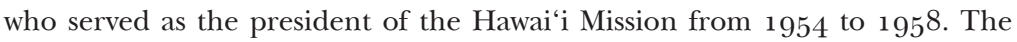
author expresses gratitude to Lynette H. Dowdle, daughter of D. Arthur Haycock and Brett D. Dowdle, grandson of D. Arthur Haycock, for providing the author with a copy of this letter, which the author has in his possession.

${ }^{69}$ William Waddoups, Monthly report to the Board of Hospitals and Settlements, May 1947 in "Records relating to Hansen's Disease, Monthly Statistical \& Narrative reports by the Superintendent of Kalaupapa Sept. 1944-July 1947," Series 26o, AH, note "Wm. M. Waddoups and Mrs. Waddoups left for Honolulu May 29th, to discontinue service on June 3rd."

${ }^{70}$ Although William retired, he apparently was still involved with providing information about the LDS Kalaupapa congregation to Hawai'i Mission President E. Wesley Smith. President Smith wrote to Elder Jack L. Halvorsen on January 21, 1948: "Recently I received some information concerning Kalaupapa and the membership there that I appreciate and value, this information received from President Wm. M. Waddoups who was for five years superintendent of the leper colony. I wrote to him in regard to the Church members and qualifications of each one." President E. Wesley Smith to Jack L. Halvorsen, January 21 , 1948, Hawai'i Mission President's Records, LR 3695 21, reel 1, box 1, folder 4, Church History Library. For a treatment on Judd's administrative years at Kalauapapa, see Fred E. Woods, "A Vow Remembered: Lawrence Judd and His Pledge to Kalaupapa," HJH, vol. 5o (2016), 1-31.

${ }^{71}$ William Waddoups, Monthly report to the Board of Hospitals and Settlement, May 1947, "Records relating to Hansen's Disease. Monthly Statistical \& Narrative reports by the Superintendent of Kalaupapa Sept. 1944-July 1947," Series $260, \mathrm{AH}$.

72 Mary Lou Bingham, interview by Fred E. Woods, July 22, 2016.

${ }^{73}$ See Letter of William Waddoups, to Elder David Hannemann, April 28, 1949, in the possession of the author, courtesy of David Hannemann.

${ }^{74}$ Dorothy O. Rea, "Thou Shalt Love Thy Neighbor as Thyself, Church News, July 9, 1966,11 . 
${ }^{75}$ William Mark Waddoups died September 2, 1956. At the back of William's 1946 journal, there is an additional note written by Olivia, which reads: "Feb. 11 th, $1957 \ldots$. [William] was taken ill with cancer Dec. 25, 1955, and was never well enough to return to the Temple. He passed away Sept. 2, 1956 at Alpine Villa Motel in Pleasant Grove, Utah where we have an apartment. ... Olivia." According to her death certificate, Olivia Sessions Waddoups passed away December 18, 1969 in Hildalgo, Texas. See https://www.ancestry.com/wiz/ Records/SEO-Records/63bo8gb6-458e-4a5c-ade 1 -b2e $35^{\text {ccb2d } 1 \text { a? action }=51}$ c69bdadf552a2egbf9o945f9egc 5 e 3 \#/ImageView (accessed April 22, 2017). William and Olivia are both buried in Bountiful, Utah, where they were born. Images of their grave markers are accessible at https://www.findagrave.com under their individual names, indicate that they are buried next to each other in Bountiful Memorial Park. 
